\title{
In Memoriam Agnes Sneller (1940-2019)
}

\author{
Prof. dr. A. Agnes Sneller als steunpilaar van de \\ internationale neerlandistiek
}

Prof. dr. A. Agnes Sneller, neerlandica en filosofe, is 31 januari 2019 overleden. Dit droevige bericht vulde niet alleen haar vakgenoten in Nederland en Vlaanderen met groot verdriet, maar ook die van de internationale neerlandistiek.

Enkele fasen van haar loopbaan waren het lesgeven op het Christelijk Lyceum Delft, de studie filosofie aan de Universiteit Leiden, een aanstelling aan de vakgroep Nederlands aldaar waar 17e-eeuwse taal en literatuur Agnes' specialiteit werd, evenals genderlinguïstiek in nauwe samenwerking met haar collega Taalbeheersing Agnes Verbiest. Ze promoveerde in 1996 bij professor dr. M.A.Schenkeveld-van der Dussen op een proefschrift met de titel Met man en macht. Analyse en interpretatie van teksten van en over vrouwen in de vroegmoderne tijd. Daarvoor schreef ze met vakgenoten de bundel Anna Maria van Schurman (1607-1678), Een uitzonderlijk geleerde vrouw (1992), met Boukje Thijs de bloemlezing Huwelijk van Jacob Cats (1993), samen met Olga van Marion en Netty van Megen De gedichten van Tesselschade Roemers (1994). De intensieve samenwerking met Agnes Verbiest leidde tot twee genderlinguïstische werken Wat woorden doen, cursusboek genderlinguistiek (2000) en Bij wijze van schrijven. Over gender en trefzeker taalgebruik (2002). Haar boek De Gouden Eeuw in gedichten van Joost van den Vondel (2014, 
verschenen in de Zeven Provinciën Reeks, waarvan ze redacteur was) is haar laatste boek geworden.

Ze organiseerde vele wetenschappelijke bijeenkomsten, samen met een team de Annie Romein-Verschoorlezingen. Ook de feestelijke viering ' 125 jaar Vrouwen in de Maatschappij der Nederlandse Letterkunde' op 26 mei 2018 ontstond op haar initiatief, waarbij er voor het eerst in de geschiedenis van de MNL vier vrouwen tot erelid werden benoemd. Dit werd voorafgegaan door de blog Dames in Data, over vijfentwintig talentvolle vrouwen met een belangwekkende inbreng in de letterkunde, taalkunde of geschiedenis (http://www.mdnl.nl), waar ze mederedacteur van was.

In 1994 heeft wijlen Erzsébet Mollay - het toenmalige hoofd van de Vakgroep Nederlandse Taal- en Letterkunde aan de Eötvös Loránd Universiteit (ELTE) te Boedapest - een fax gestuurd naar vakgroepen Nederlands in Nederland en Vlaanderen, onder andere de Vakgroep Nederlands aan de Universiteit Leiden, met de vraag of een collega haar aan de ELTE gedurende een semester kon vervangen vanwege haar studieverlof. In september 1994 kwam Agnes naar de ELTE te Boedapest om die colleges van Erzsébet over te nemen. Uit die eerste groep derdejaars aan wie ze les gaf, zijn veel vakgenoten voortgekomen, zoals bijvoorbeeld Anikó Daróczi, nu al jaren hoofd van de Vakgroep Nederlandse Taal- en Letterkunde aan de Károli Gáspár Universiteit. Agnes werd ook uitgenodigd in Debrecen om daar op de Vakgroep Neerlandistiek gastcolleges te geven. Het was in deze tijd dat we voor het leven vriendschap sloten.

Met haar collega Agnes Verbiest trad ze in 1995 op een studiedag van de ELTE op waarbij de gehele Hongaarse neerlandistiek aanwezig was. Ze hadden het over genderlinguïstiek en gaven workshops rond dit thema. $\mathrm{Zij}$ waren de allereerste gastdocenten van een evenement dat sindsdien bijna dertig jaar bestaat. Het verhaal over gender was voor vele Hongaarse studenten en docenten een eyeopener.

Agnes is daarna een aantal malen teruggekomen voor gastcolleges; eerst alleen aan de ELTE, de Károli en de Universiteit Debrecen, later ook in de regio Centraal- en Oost-Europa.

Ze werd voor de periode januari 2000 tot december 2002 uitgenodigd om op de Károli Universiteit de Vakgroep Nederlands aldaar te helpen professionaliseren. Ze gaf leiding aan de vakgroep, bezorgde werk- en hoorcolleges over historische taalkunde en genderlinguïstiek, begeleidde scripties en stimuleerde onderzoek. Dit laatste heeft onder andere geleid tot de uitgave van de reeks Károli Studies. Daarnaast heeft ze veel gedaan 
voor de samenwerking van de drie vakgroepen neerlandistiek in Hongarije. Ze werd enkele jaren voor haar pensioen hoogleraar aan de Károli Gáspár Universiteit.

In die jaren heeft ze ook intensief deelgenomen aan vrijwel alle activiteiten die in Comeniusverband werden georganiseerd. Ze heeft op congressen opgetreden, talloze artikelen gepubliceerd in en geredigeerd voor uitgaves van de vakgroepen Neerlandistiek in Midden- en OostEuropa. Belgrado, Boekarest, Bratislava, Olomouc, Riga, Warschau, Wenen, Wroclaw - ze was overal een graag geziene gastdocent. Agnes was een onuitputtelijke bron van inspiratie voor zowel docenten als studenten. Wij konden altijd heel veel over de methodiek van onderwijs en onderzoek, over feministisch taal- en literatuuronderzoek en nog een heleboel andere dingen van haar leren. Ik heb niemand gekend die zo hard kon werken en anderen zo hartelijk hulp verleende; hulp voor de ziel, hulp in het werk. Agnes heeft overal grote indruk gemaakt, enthousiasme en vrolijkheid gezaaid, vriendschappen gesloten. Ze had een bijzonder goed gevoel van humor en kon lachen als niemand anders: uit heel haar hart.

Op grond van haar voortdurende en uitnemende activiteiten op het gebied van de neerlandistiek in Centraal Europa is Prof. dr. A. Agnes Sneller in 2005 erelid van de Comenius Vereniging geworden. Vanuit haar betrokkenheid met de internationale neerlandistiek hebben wij samen een cursusboek Inleiding literatuurgeschiedenis voor de internationale neerlandistiek geschreven dat in 2010 bij Uitgeverij Verloren uitkwam.

De diepte en de dimensies van haar werk op het gebied van de internationale neerlandistiek gedurende meer dan vijfentwintig jaar zijn moeilijk te beschrijven: ze leerde ons werkethiek, discipline, optimisme en het belang van het samenwerken. Haar politieke, sociale en academische betrokkenheid was bewonderenswaardig. Agnes was iemand met een boodschap. Een boodschap van solidariteit, doorzettingsvermogen en belangstelling voor de ander. Agnes is een begrip geworden. We zullen haar ontzettend missen, niet vergeten en haar boodschap meenemen. 